\title{
Donde habitan los ángeles
}

Celis, Claudia

2007

Ediciones SM,

México

\section{Juan Carlos Gaitán Izaguirre}
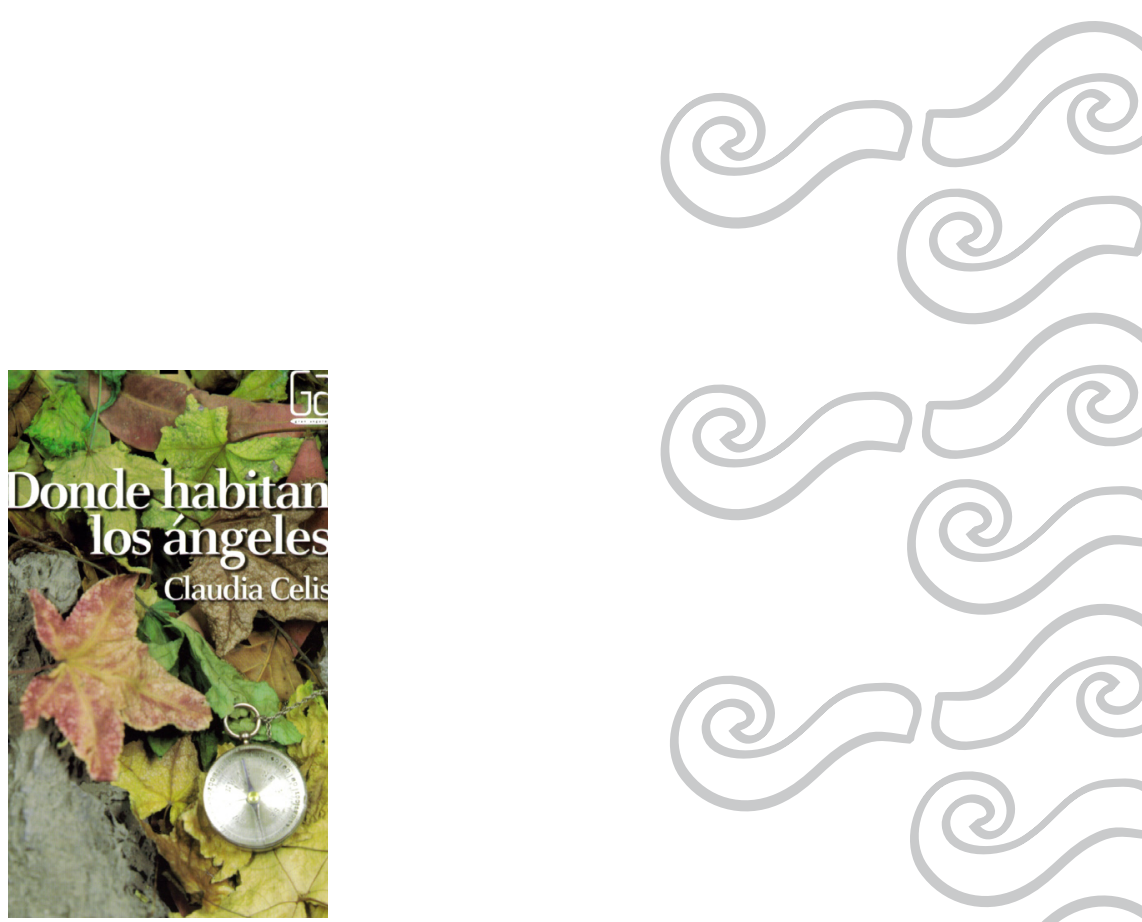

El libro Donde habitan los ángeles es una novela muy sencilla de leer, la cual narra una historia a lo largo de 117 páginas, dividida en cuarenta y dos capítulos de no más de cinco páginas cada uno, lo cual hace muy ligera la lectura y propone terminarlo "de una sentada".

El texto cuenta la historia de Pancho, un chico huérfano de padre y que no cuenta con su madre; narra sucesos y anécdotas que marcaron la vida de este muchacho y su aprendizaje a través de ésta, desde sus primeros años de primaria hasta que termina la universidad.

La autora provoca que el lector experimente diferentes emociones como tristeza, alegría, enojo, suspenso, risa, al paso de los capítulos.

Muestra a lo largo de la historia una figura paterna, que es el tío abuelo de Pancho, su Tío Tacho, quien funge como el que aporta el conocimiento, usando métodos inusuales pero predecibles para transmitir sus enseñanzas; y también una figura materna, su Tía Chabela, quien media la relación entre estos dos personajes.

${ }^{1}$ Alumno de sexto semestre de Universidad La Salle Pachuca, Bachillerato

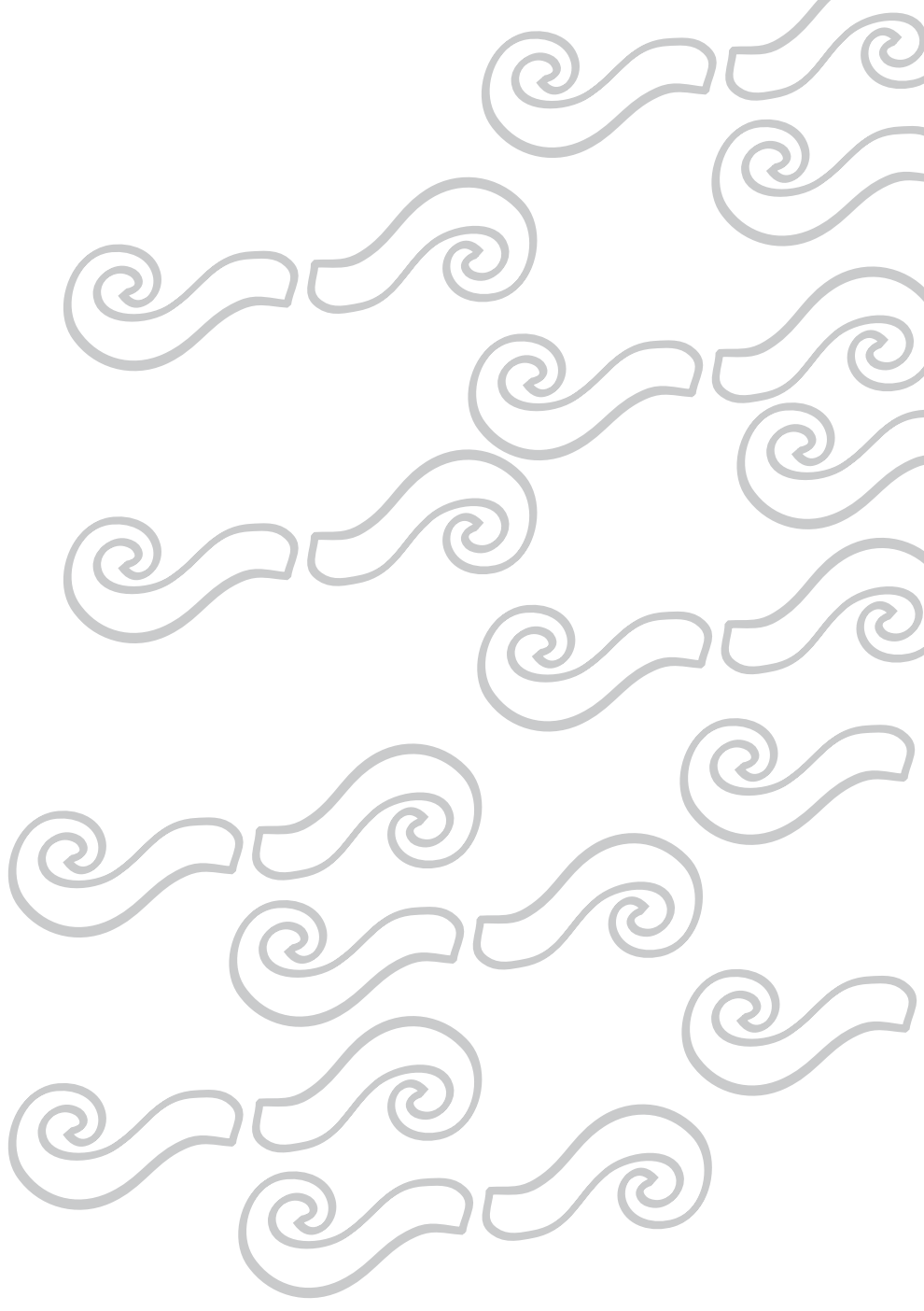

